\title{
Gated communities revisited: defended homes nested in security enclaves
}

\author{
Sarah Blandy* \\ University of Sheffield
}

\begin{abstract}
This article reviews developments over the past ten years which have led to an increase in architectural and technological defensiveness of both individual homes and of neighbourhoods. It argues that this is the result of a combination of prevailing structural conditions: neoliberal state policies that bolster responsible home ownership and aim to reduce public spending; an emphasis on the market which opens the way for developers and the security, insurance and associated industries to make profits; loss of place-based community which cannot be replaced by the legal frameworks which bind the residents of private enclaves; an increase in house prices causing homes to be viewed primarily as financial assets; fear of crime fuelled by the media; and a lack of government policies to prevent the further growth of gated communities.
\end{abstract}

Keywords: defended homes; gated communities; tessellated neoliberalism.

The editors' invitation gives me an opportunity to reflect on gated communities and their societal effects over the past decade, both in the context of a generally more fearful and individualistic attitude to the home and in the context of the economic and ideological policies and forces associated with this trend. In the ten years since my paper 'Gated communities in England as a response to crime and disorder' was published in PPP, this form of housing has proliferated across the world. Research into gated communities and the issues they raise has followed suit, and there are now so many relevant publications that it would be impossible to cite them all here. Much of this research has been descriptive and very context-specific, but there have been some comparative publications which help us to understand the different drivers for the spread of gated communities in different countries, and to consider whether it is possible to draw any general conclusions (see, for example, Bagaeen and Uduku, 2015).

The 2007 PPP paper was based on research into gated communities carried out in England in 2002-2003 by myself, Rowland Atkinson, John Flint and Diane Lister. Rowland and I then started to notice that many single homes were becoming fortified. As well as enclosed housing developments behind barriers, with legal arrangements for self-governance (i.e. gated communities), many ordinary suburban homes now display security features such as lockable electronic gates, spike-topped walls and fences, internal and external iron grilles at the windows, burglar alarms and CCTV. The concept of defensive homeownership was developed for our recent book (Atkinson and Blandy, 2017) and I will draw on some of those ideas to argue that fortress homes and 
defended enclave neighbourhoods are part of the same interconnected pattern, albeit at different scales.

\section{Neoliberalism and its effects}

The pattern of defended homes and neighbourhoods which we increasingly see today has complex roots. The long-established association of the home with control, security, privacy and status (see for example, Mallett, 2004) is certainly important in the development of this pattern, and has also been central to the encouragement of homeownership and individual responsibility by western governments over the course of the twentieth century. This in turn ties in with the neoliberal ideology which has become dominant over the past few decades, which emphasises individual choice and reliance on market forces rather than state provision. The same period has also been marked by an unprecedented growth in house values, meaning that more homeowners are likely to view their home as above all an asset to be protected. The financial crash saw most homeowners protected from mortgage dispossession by government intervention, and in many areas house prices recovered surprisingly quickly. Although homeownership has declined as a proportion of the housing stock, the pressure to 'get on the housing ladder' and the aspiration to own one's home has not diminished. As well as a financial asset, the owned home has become very much a symbol of status and prestige, adding to the perceived need to protect it against a range of threats. The most acute of these threats is burglary which is often experienced as a personal violation and, if the intruder enters the home while the householder is in, a terrifying event. Housing developers market home security features to allay such fears, and the security and insurance industries also profit along with the builders of safe homes and gated communities.

Neoliberal policies have also led to a gradual withdrawal of the state from public provision such as welfare and policing. These policies have had significant effects in decreasing the level of acceptance of social responsibility for those outside the home circle of family and close friends. Greater reliance on market forces has accelerated inequality in term of wealth. This, alongside greater mobility of labour and increased immigration, has reduced social homogeneity. There has been a gradual trend to perceive 'people not like us' as 'others' to be feared as potential intruders, causing a further withdrawal into the security of the home. Further, the late modern era has been characterised by an increased awareness of risks of all kinds. Coupled with the neoliberal emphasis on individual responsibility, this means that for the ordinary individual citizen exclusionary strategies have become, for the first time, a viable general response to the challenge of social interaction' (McLean, 1999: 17). As trust in other people diminishes, the home becomes a protected haven, ever more disconnected from the public realm.

Simultaneously, social changes over the same decades, for example women working outside the home and more recently the rise in use of social media networks, have also led to a loss of place-based community. The importance of the neighbourhood as a key site of social belonging has diminished. Instead, its role has now changed into providing the background 'locality' of the individual home, with a very significant effect on its value - as the estate agents constantly remind us. The home as a source of affluence seems to have trumped the attraction of a more collective way of life. Interestingly, many gated communities are marketed through a nostalgic appeal to the image of a warm and supportively friendly neighbourhood. However, such enclaves can be seen as artificial neighbourhoods, held together by legal documents and enforceable obligations rather than social ties between the residents. In recent years 
one strand of research into gated communities has focused on their internal governance arrangements. Each jurisdiction has adopted its own particular legal framework(s) for this type of multi-owned housing but some problems appear to be common, whether arising from strata title developments as in Australia and Singapore, from leasehold sites as in England and Wales, or from common interest developments as in the US (see McKenzie, 2011; Blandy et al, 2010). Many research projects in different jurisdictions have found that most enclave residents have not consciously chosen a self-governing community and tend to be dissatisfied with their governance arrangements. Neighbourhood life varies widely between gated developments, from a genuine community to little contact between neighbours. The mutually binding rules attached to all properties in gated communities often do not provide an effective substitute for the informally negotiated social norms found in neighbourhoods which have developed more organically.

A high proportion of the planners in English local authorities who were interviewed for our original research (Atkinson et al, 2004) expressed their concern about the spread of gated communities, on the grounds of their negative impact. Planners cited reduced spatial connectivity, deterioration in social integration and the displacement of crime as key factors. However, we found few planning policies that might have provided an effective response. This gap in the planning system is also evident in, for example, Canada (Grant, 2005) and in Argentina (Thuillier, 2005). Research has established that developers often form alliances with local governments, which are understandably keen to attract high profile housing developments to their area, and thus the planners' concerns are sidelined (see Blandy and Wang, 2013). The neoliberal emphasis on market and profit, and state encouragement for residents to take responsibility for their own homes and self-governing neighbourhoods, provides the underpinning for the growth in gated communities.

\section{Fear of crime, and effectiveness of gating}

Further underpinning for the growth of gated communities and home security in general, is provided by a generalised fear of crime and the perceived need to protect the home. Fear of crime levels remain stubbornly high even in areas and countries where crime rates have consistently dropped over the past few decades. The media certainly has to take some responsibility for this (see extended discussion in Atkinson and Blandy, 2017). Over the past decade there have been few studies into the effectiveness of gating in preventing crime or decreasing fear of crime, some of which are discussed later. Nuanced research often shows that in fact fear of crime is not the main driver for residents to move into gated communities (see Genis, 2007, in relation to Turkey; and Cséfalvay, 2011, in relation to Budapest, Hungary). However, in countries with high levels of violent crime, fear of crime is no doubt a very important factor. Yet there, interestingly, gating does not seem to provide peace of mind. For example there has been a dramatic increase in crime rates in Mexico City in recent years, but empirical findings into residents' fear of crime when home alone show that living in a gated community does not reduce anxiety. Rather, an individual's level of fear of crime is more closely associated with gender, educational attainment, social class, general levels of fear of crime in the wider neighbourhood, and degree of trust in the local police (Vilalta, 2011). This may be less surprising when taking into account that where research into the effectiveness of gating has been undertaken, it has consistently failed to show that defended enclaves are less vulnerable to crime than ungated neighbourhoods. Indeed, a study of Thswane, South Africa, an area with high levels of violent and property crime, found a significant positive association with burglary rates in both day and night time, suggesting that residing in a gated 
community actually increased the risk of burglary victimization (Breetzke and Cohn, 2013).

One of the reasons why planners are concerned about gated developments is the displacement of crime to other areas. Certainly, this appears to be an important motivation for residents who appeal for their neighbourhood to be gated. Such appeals are frequent in South Africa, where planning permission can be granted for retro-gating. In suburban Cape Town, residents' fear was manifested in the desire for the physical security of a gated community; they wanted both criminal acts and feared 'others' to be displaced elsewhere, predominately into socio-economically weaker areas (Lemanski, 2006). Retro-gating in England is much rarer; here, it would be less likely for a neighbourhood to obtain planning permission to turn itself into an enclave. However, some time ago the London Borough of Camden started to enclose its council housing estates. One resident explained the effect on his estate of Camden Council "closing up all the other estates. All the undesirables came here... you know, burglars and all sorts. It wasn't just displacing - it was magnifying the problem' (Interview with leaseholder, quoted in Blandy, 2011). The residents of that estate vociferously demanded that they be protected by a new perimeter fence, which was duly built, but with mixed results in terms of both actual crime rates and fear of crime amongst residents.

Nor can gating eliminate crime committed by one resident against another inside the enclave. Walls, gates and guards designed to exclude outsiders cannot possibly address the highly gendered risk of violence within, as shown by an analysis of murders committed within US gated communities (Atkinson and Smith, 2012). Yet gated communities continue to be popular with purchasers, to make money for developers, and offer the false promise of freedom from anxiety. In her anthropological studies of gated communities in the US, Setha Low has found that residents experience 'feelings of insecurity, fear, paranoia, worry and status anxiety' (Low, 2008: 49). Of particular concern is the effect on children who have been brought up behind walls and fences, who exhibit 'an obsession with safety and security', leading to them feeling unnecessarily vulnerable and fearful of others when outside their protected environment (ibid). There has as yet been no research into the effect of living in an individual fortified home, but this experience is likely to mirror the studies which show how anxiety is, paradoxically, amplified by the security features in gated communities: 'every extra lock on the entry door ... makes the world look more treacherous and fearsome, and prompts still more defensive actions that will add still more vigour to the self-propagating capacity of fear' (Bauman, 2006: 143, original emphases).

\section{Segregation}

Homogenous, virtually segregated, neighbourhoods are nothing new and certainly predate gated communities in most areas of the world. However, in the past few decades the affluent have established on a global scale "more and more finely distinguished "lifestyle enclaves", segregated by race, class, education, life stage and so on' (Putnam, 2000: 209). Although these enclaves are by no means all enclosed and protected, actual gated communities are a very potent, physical symbol of this chosen segregation. In southern California, the walls around defended neighbourhoods define territories which are homogenous particularly in relation to income levels and age; they are thus associated with very significant socio-economic dissimilarities (Le Goix, 2005). A parallel urge for self-segregation, expressed through the prestige of owning a home in a high value gated community, is posited as the major motivation for residents in Budapest, rather than fear of crime (Cséfalvay, 2011). It is in any case difficult to distinguish between a fear of crime, and a fear of 'others', as the primary 
motivation for residents to fortify their homes and/or move into gated communities. Research in Guangzhou, China, found that gated community residents had a strong desire to separate 'insiders' from 'outsiders', while their justification for gating was based on the interrelated factors of heightened security, sense of belonging, and a good living environment (Breitung, 2012).

Two recent anthropological studies in the US have started to shed light on the connections between gated communities and segregation by race. Low (2009) carried out research in the gated suburbs of New York City and San Antonio, Texas. She found that residents there employed two mechanisms for maintaining whiteness and white privilege. The first was the fear of others, used to justify excluding 'others' from their gated community. The second was the desire for 'niceness', a concept which focuses on the way people make moral and aesthetic judgments to control their social and physical environments. In combination, these mechanisms inscribe racist assumptions on the landscape. The well-off residents themselves were found to be largely unaware of this process, experiencing it as natural and taken for granted. These findings are complemented by those from a very different study of working-class white seasonal retirees living in fortress communities in South Texas, surrounded by a wealthier, mainly Latino, settled population (Foiles Sifuentes, 2015). Here, the residents made use of overt racism to deter 'others' from moving in, as a means of obtaining, maintaining, and securing spaces of white exclusivity. It is well known that an external threat can create unity amongst groups of people. Residents of gated communities are no exception, despite the characteristic lack of community within such neighbourhoods noted above. It may be that the physical and legal boundaries of a gated community serve to reinforce a feeling of solidarity which in turn justifies the use of strategies to exclude unwanted 'others'.

\section{Conclusions}

Looking back over developments in the past ten years, it is clear that the forces which create conditions for increased home security and the spread of gated communities have the upper hand at present. The phrase 'tessellated neoliberalism' was coined (Atkinson and Blandy, 2017) to express how market values are materialised in an interlocking pattern of domestic fortresses and defended neighbourhoods. What has been aptly termed 'the gating machine' (Vesselinov et al, 2007) comprises a potent combination of prevailing structural conditions: neoliberal state policies that bolster responsible home ownership and aim to reduce public spending; an emphasis on the market which opens the way for developers and the security, insurance and associated industries to make profits; loss of place-based community; an increase in house prices causing homes to be viewed primarily as financial assets; fear of crime fuelled by the media; and a lack of will and policies by local governments to prevent the further growth of gated communities. With the accompanying rise in security technologies designed and marketed for the protection of individual homes, gated communities now emerge as a visible intermediate layer of defence between the home and national territories.

* Correspondence address: Sarah Blandy, School of Law, University of Sheffield, UK. Email: s.blandy@sheffield.ac.uk 


\section{References}

Atkinson, R. and Blandy, S. (2016) Domestic Fortress: Fear and the New Home Front. Manchester: Manchester University Press.

Atkinson, R., Blandy, S., Flint, J. and Lister, D. (2004) Gated communities in England. London: Office of the Deputy Prime Minister.

Atkinson, R. and Smith, O. (2012) An economy of false securities? An analysis of murders inside gated residential developments in the United States. Crime Media Culture, 8, 161-172.

Bagaeen, S. and Uduku, O. (2015) Beyond Gated Communities. London/New York: Routledge.

Bauman, Z. (2006) Liquid Fear. Cambridge: Polity.

Blandy, S. (2011) Gating as governance: the boundaries spectrum in social and situational crime prevention, In: Crawford, A. (ed) International and Comparative Criminal Justice and Urban Governance, 519-544. Cambridge: Cambridge University Press.

Blandy, S., Dixon, J. and Dupuis, A. (eds) (2010) Multi-owned Housing: Law, Power and Practice. Aldershot: Ashgate.

Blandy, S. and Wang, F. (2013) Curbing the power of developers? Law and power in Chinese and English gated urban enclaves. Geoforum, 47, 199-208.

Breetzke, G.D. and Cohn, E.G. (2013) Burglary in Gated Communities: An Empirical Analysis Using Routine Activities Theory. International Criminal Justice Review, 23, 1, 56-74.

Breitung, W. (2012) Enclave Urbanism in China: Attitudes towards Gated Communities in Guangzhou. Urban Geography, 33, 2, 278-294.

Cséfalvay, Z. (2011) Gated Communities for Security or Prestige? A Public Choice Approach and the Case of Budapest. International Journal of Urban and Regional Research, 35, 4, 735-752.

Foiles Sifuentes, A.M. (2015) Compound Communities: Fortifying Socioeconomic and Racial Barriers in South Texas Border Towns. North American Dialogue, 18, 1, 15-25.

Genis, S. (2007) Producing elite localities: the rise of gated communities in Istanbul. Urban Studies, 44, 4, 771-798.

Grant, J. (2005) Planning Responses to Gated Communities in Canada. Housing Studies, 20, 2, 273-285.

Le Goix, R. (2005) Gated Communities: Sprawl and Social Segregation in Southern California. Housing Studies, 20, 2, 323-343.

Lemanski, C. (2006) Residential responses to fear (of crime plus) in two Cape Town suburbs: implications for the post-apartheid city. Journal of International Development, 18, 6, 787-802.

Low, S. (2009) Maintaining Whiteness: The Fear of Others and Niceness. Transforming Anthropology, 17, 2, 79-92.

Low, S. (2008) Fortification of Residential Neighbourhoods and the New Emotions of Home. Housing, Theory and Society, 25, 1, 47-65.

Mallett, S. (2004) Understanding Home: A Critical Review of the Literature. The Sociological Review, 52, 1, 62-89.

McKenzie, E. (2011) Beyond Privatopia: Rethinking Residential Private Government. Washington DC: Urban Institute Press.

McLean, J. (1999) Property and the Constitution. Oxford: Hart.

Thuillier, G. (2005) Gated Communities in the Metropolitan Area of Buenos Aires, Argentina: A challenge for Town Planning. Housing Studies, 20, 2, 255-271.

Vesselinov, E., Cazessus, M., Falk, W. (2007) Gated Communities and Spatial Inequality. Journal of Urban Affairs, 29, 2, 109-127. 
p. 142. Gated communities revisited: defended homes nested in security enclaves

Vilalta, C.J. (2011) Fear of crime in gated communities and apartment buildings: a comparison of housing types and a test of theories. Journal of Housing and the Built Environment, 26, 2, 107-121. 